\title{
Antimicrobial susceptibility of commensal Escherichia coli from faeces of apparently healthy white fulani cattle (Bos indicus)
}

Ruth F. Aminu ${ }^{1 *}$ and Ishaleku David ${ }^{2}$

*Correspondence: ruthaminu@yahoo.com

'Department of Microbiology, Kogi state University, Anyigba, Nigeria.

${ }^{2}$ Department of Biological Sciences, Microbiology Unit, Nasarawa state University Keffi, Nigeria.

\begin{abstract}
Antimicrobial susceptibility of commensal Escherichia coli (E. coli) from faecal samples of white Fulani cattle (Bos indicus) was determined in Anyigba, Kogi state. Sixty (60) faecal samples were collected from four Fulani settlements between February 2012 and July 2013. E. coli from faecal samples was isolated and identified using standard microbiological and biochemical methods. Isolates were tested with 6 antimicrobials drugs commonly used in the treatment of human and veterinary infections by disk diffusion technique. Of these isolates $8.5 \%$ were sensitive to all the antibiotics. Azithromycin had the highest $(76.6 \%)$ resistance, while cefuroxime and tetracycline were $51.1 \%$ and $40.4 \%$ respectively. Resistance to Ciprofloxacin and amoxicillin/clauvulanic acid was however low (10.6\% and $17.0 \%)$. The study further revealed that $31.9 \%$ of the isolates were resistant to more than 3 antibiotics. The prevalence of co-resistance of azithromycin with Cefuroxime and Tetracycline was $46.7 \%$ among the multidrug resistant isolates. Strict hygienic measures are imperative in slaughter and processing of beef to avoid transmission of these antimicrobial resistant bacteria to food. Farmers using cow dung as organic manure should be enlightened on adequate measures of composting and decontamination to prevent the spread of these antibiotic resistant bacteria to farm produce, human and animals.
\end{abstract}

Keywords: Commensal E. coli, cattle, antimicrobial susceptibility, faeces, Kogi state

\section{Introduction}

Escherichia coli, is a common microbial flora of the gastrointestinal tract of human beings and vertebrate animals [1]. Apart from being shed in faeces, its presence has also been detected in soil, plants and in water where it could serve as one of the factors affecting animal and human health. It is estimated that $1-4 \%$ of all cultured bacteria of the colon are E. coli. Commensal E. coli strains are thought to maintain the physiological milieu of the gut and support digestion, as well as defend against enteric pathogens [11].

Faeces pollution of water and food is an environmental problem of increasing importance. Identification of individual host sources of faecal E. coli such as human, domestic animals and wild animals is a prerequisite to the formulation of remediation plans [3]. Possible sources of faecal contamination include surface runoff from manure treated agricultural and or farm animal feedlots and inadequate septic systems, sewer overflow and wildlife.

Antimicrobials have played an indispensable role in decreasing illness and death associated with infectious diseases in animals and humans. However, selective pressure exerted by antimicrobial drug used has also been the major driving force behind the emergence and spread of drug resistance traits among pathogenic and commensal bacteria. Recent studies have shown that commensal bacteria of humans and animals could serve as good indicators of antimicrobial selective pressure and reveal the potential for antimicrobial resistance emerging in enteric pathogens [10]. The French Institute for Public Health Surveillance has recommended that studying antimicrobial resistance in commensal bacteria from healthy animals would, 
therefore be extremely valuable, as these organisms could serve as a reservoir for genes that encode antimicrobial resistance and given the right conditions, could transfer these resistant genes to pathogenic bacteria [6].

This study therefore was carried out to assess the level of antimicrobial susceptibility of commensal Escherichia coli in the faeces of apparently healthy white Fulani cattle in Anyigba, Kogi state.

\section{Materials and methods}

This study was carried out among four Fulanicattle herds in Ayingba, Kogi state in the North central zone of Nigeria.

\section{Sample collection}

Sixty (60) freshly laid faecal samples were collected from four herds of apparently healthy white Fulani cattle in Anyigba from February 2012-July, 2013. Fifteen faecal samples were collected from each herd into sterile universal containers, aseptically labelled and transported to the laboratory for microbiological analysis.

\section{Isolation of $E$. coli}

Approximately $1 \mathrm{~g}$ of each faecal sample was emulsified in $9 \mathrm{ml}$ of phosphate buffered saline (PBS). The 10 -fold serial dilution was performed until $10^{-7}$ dilution was obtained. Pour plate technique was employed in the isolation of the bacteria by inoculating $0.1 \mathrm{ml}$ of the $10^{-7}$ dilution unto molten MacConkey agar plates. Upon solidification, plates were incubated at $37^{\circ} \mathrm{C}$ for 24 hours. The typical lactose fermenting colony from each faecal sample with deep pink colouration were subculture onto Eosin Methylene Blue (EMB) agar at $37^{\circ} \mathrm{C}$ for 24 hours. Single colonies with greenish metallic sheen on EMB were confirmed using standard biochemical tests.

\section{Antimicrobial susceptibility testing}

Antimicrobial susceptibility testing was conducted by the disk diffusion method. Test isolates were inoculated into peptone water with a turbidity conforming to $0.5 \mathrm{McF}$ arland turbidity standards. A sterile glass rod was employed each time to evenly spread $0.1 \mathrm{ml}$ of the inoculums into prepared plates of Mueller Hinton agar plates and allowed to dry for 5 minutes. Antibiotic discs (Oxoid England) were ciprofloxacin $(5 \mu \mathrm{g})$, amoxicillin/ clavulanic acid $(30 \mu \mathrm{g})$, azithromycin $(15 \mu \mathrm{g})$, cefuroxime $(30 \mu \mathrm{g})$, nalixidic acid $(30 \mu \mathrm{g})$, and tetracycline $(30 \mu \mathrm{g})$. The antimicrobial discs were evenly placed on the surface of the plates using sterile forceps. Plates were incubated at $35^{\circ} \mathrm{C}$ for 18 hours. Zones of inhibition were measured in millimetres and were interpreted as sensitive, intermediate or resistant according to the CSLI (Clinical and Laboratory Standard Institute 2011) breakpoints for the antibiotics used. E. coli ATCC 25922 was used as a control.

\section{Multidrug resistance (MDR)}

Escherichia coli isolates exhibiting resistance to $\geq 3$ antimicrobials were regarded as multidrug resistant (MDR). Concurrent resistance of the isolates to the antimicrobials was also evaluated.

\section{Results}

Forty seven (78.3\%) Escherichia coli isolates obtained from 60 faecal samples were subjected to the antimicrobial susceptibility testing. Of these isolates, $63.8 \%, 53.2 \%$ and $46.8 \%$ were susceptible to ciprofloxacin, tetracycline and amoxicillin/clavulanic acid respectively. E. coli resistance to azithromycin was $76.6 \%$, while resistance to cefuroxime and tetracycline were $51.1 \%$ and $40.4 \%$ respectively (Figure 1). More than $63 \%$ of the isolates exhibited intermediate susceptibility to nalixidic acid though resistance to the drug was low (12.7\%). Intermediate susceptibility of isolates to amoxicillin/clavulanic acid (36.2\%) and ciprofloxacin (25.5\%) followed, but higher sensitivity of the isolates to these drugs were recorded ( $46.8 \%$ and $63.8 \%$ respectively) compared with nalixidic acid (23.4\%).

Co-resistance of azithromycin with cefuroxime (AZM-CXM) was the most frequently observed (42.6\%) (Table 1). AZM-TE followed with $10.6 \%$, while $8.5 \%$ of the isolates were susceptible to all the antimicrobial agents tested while only $2.1 \%$ were resistant to all antimicrobials tested. Multidrug resistance (MDR) of the faecal E. coli isolates was 31.9\% (Table 2) AZM-TE was the most commonly observed MDR profile (26.7\%).

\section{Discussion}

The antimicrobial susceptibility of commensal E. coli isolated from faeces of white Fulani cattle revealed that antimicrobial resistance is on the increase even among commensal bacteria and has become a growing problem. This is due to overuse of antibiotics in humans, and use of antibiotics as growth promoters in animal feeds [7]. Antimicrobial resistance in food animals deserves special attention. Escherichia coli is an indicator species for studies of the level of antibiotic resistance of the faecal flora [12]. Escherichia coli make their way into the food chain via the faecal contamination of animal carcases during slaughter, with subsequent improper handling (storage and cooking) of the product or by faecal adulteration of agricultural crops in the field or packing sheds.

Antimicrobial resistance of $E$. coli to azithromycin and tetracycline $(76.6 \%$ and $40.4 \%)$ observed in this study was lower than that reported by many authors for pathogenic E. coli. For

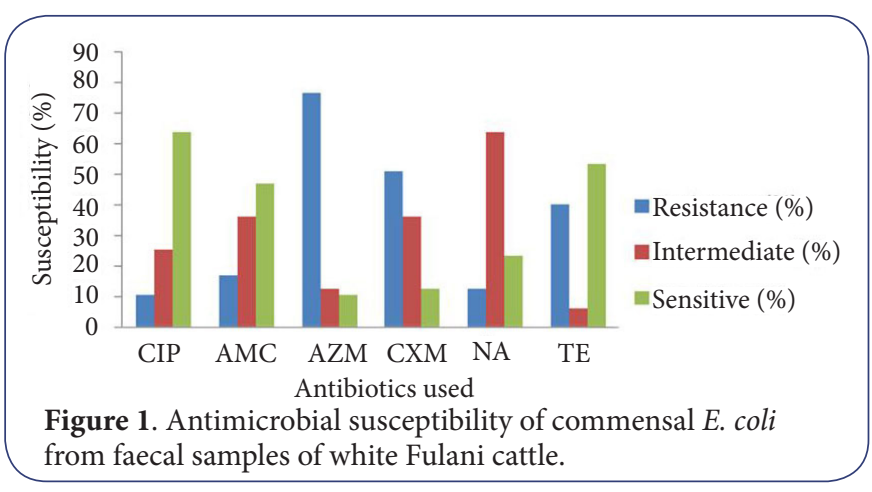


Aminu et al. Microbiology Discovery 2015,

Table 1. Antimicrobial resistance patterns of faecal $E$. coli of white Fulani cattle.

\begin{tabular}{l|l|l}
\hline \multirow{2}{*}{$\begin{array}{l}\text { No. of antimicrobials } \\
\text { resistant }\end{array}$} & \multicolumn{2}{c}{ Cattle isolates (n=47) } \\
\cline { 2 - 3 } & $\begin{array}{l}\text { Antimicrobial resistance } \\
\text { pattern (ARP) }\end{array}$ & $\begin{array}{l}\text { Frequency } \\
\text { of ARP }\end{array}$ \\
\hline 0 & 0 & 4 \\
1 & AZM; CXM; TE & $7 ; 3 ; 3$ \\
2 & AZM-CXM; AZM-TE; & $9 ; 5 ; 1$ \\
& CIP-CXM & \\
3 & AZM-CXM-TE; AZM-CIP- & $4 ; 1 ; 1 ; 2 ; 1$ \\
& CXM; AZM-AMC-CXM; \\
& AZM-AMC-TE; AZM- \\
& CXM-NA \\
& AZM-AMC-CXM-NA; & \\
4 & AZM-CIP-NA-TE; \\
& AZM- AMC-CXM-TE \\
& AZM-AMC-CXM-NA-TE; & $1 ; 1$ \\
5 & AZM-CIP-AMC-NA-TE \\
& AZM-AMC-CIP-CXM-NA- 1 \\
6 & TE \\
\hline
\end{tabular}

Key: $\mathrm{AMC}=$ amoxicillin/clavulanic acid; $\mathrm{AZM}=$ azithromycin; $\mathrm{CXM}=$ cefuroxime; $\mathrm{CIP}=$ ciprofloxacin; $\mathrm{NA}=$ nalixidic acid; $\mathrm{TE}=$ tetracycline

Table 2. Antimicrobial resistance profile of $E$. coli isolates $(\mathrm{n}=47)$.

\begin{tabular}{lll}
\hline $\begin{array}{l}\text { No. of } \\
\text { Antimicrobial }\end{array}$ & $\begin{array}{l}\text { No. of isolates } \\
\text { with profile }\end{array}$ & \\
\hline 6 & 1 & 2.1 \\
5 & 2 & 4.3 \\
4 & 3 & 6.4 \\
3 & 9 & 19.1 \\
2 & 15 & 31.9 \\
1 & 13 & 27.7 \\
0 & 4 & 8.5 \\
\hline
\end{tabular}

instance, $85.4 \%$ resistance to azithromycin among enterobacteria family tested from different clinical samples [4]. Obireet al., (2008) reported a 79.2\% resistance of $E$. coli isolated from patients to Tetracycline.

Antimicrobial resistance is typically more frequent among pathogens than in commensal bacteria [2]. This difference is generally attributed to the more intense and repeated exposure of pathogens to antimicrobial agents.

The emergence of multidrug resistance (MDR) bacteria has complicated the issue of antimicrobial resistance. This is said to be common among Gram negative bacteria [8]. The 31.9\% prevalence of MDR recorded in this study is in agreement with that reported from healthy lactating cattle in 2007 [10]. Higher level of susceptibility of $E$. coli to Ciprofloxacin (89.3\%) observed is consistent with reports of $80 \%$ and $80.1 \%$ sensitivity of $E$. coli in food animals respectively $[\mathbf{1 4 , 1 5}]$. This may be an indication that this drug is still useful in the treatment of bacterial infections. An understanding of the associations between phenotypic resistance and resistance genes may have important implications for the design of effective prudent-use guidelines [6].

\section{Conclusion and recommendation}

The pattern of antimicrobial resistance (AMR) recorded in this study for commensal bacteria of healthy cattle implies that strict hygienic measures must be taken in the slaughter of cattle and processing of beef for food to avoid transmission of these resistant bacteria to food. Proper disposal of cow dung must be ensured. Farmers using cow dung as organic manure should be enlightened on adequate measures of compositing and decontamination to avoid transmission of antimicrobial resistant microbes to farm produce, humans and animals. Nomadic nature of the Fulani cattle herders may also be a risk factor in the spread of antibiotic resistant bacteria. There is a need to educate nomads on hygienic measures including hand washing and proper disposal of cattle dungs.

\section{Competing interests}

The authors declare that they have no competing interests.

\section{Acknowlegement}

The authors wish to express their profound gratitude to the Fulani herders who allowed us to collect fecal samples and also wish to thank the technical staff of the Microbiology department of the Kogi State University, Anyigba for their assistance in the analysis.

\section{Publication history}

Received: 17 October 2014 Revised: 08 January 2015

Accepted: 20 January 2015 Published: 24 January 2015

\section{References}

1. Arshad R, Farooq S and Ali S.S. Manipulation of different media and methods for cost-effective characterisation of $E$. coli strains collected from different habitats. Pak. Jou. Bot. 2006; 38:779-789. | Article

2. Boerlin P, Travis R, Gyles CL, Reid-Smith R, Janecko N, Lim H, Nicholson $\mathrm{V}$, McEwen SA, Friendship $R$ and Archambault M. Antimicrobial resistance and virulence genes of Escherichia coli isolates from swine in Ontario. Appl Environ Microbiol. 2005; 71:6753-61. | Article | PubMed Abstract | PubMed FullText

3. Canton R. Antibiotic resistance genes from the environment: a perspective through newly identified antibiotic resistance mechanisms in the clinical setting. Clin Microbiol Infect. 2009; 15 Suppl 1:20-5. I Article | PubMed

4. Carson C.A, Shear B.L, Ellsiek MR and Asfaw A. Identification of faecal Escherichia coli from human and animals. Appl Environ. Microbiol. 2001; 67:1503-1507. | Article

5. Chayani N, Tiwari S, Sarangi G, Mallick B, Mohapatra A, Paty BP and Das $P$. Role of azithromycin against clinical isolates of family enterobacteriaceae: A comparison of its minimum inhibitory concentration by three different methods. Indian J Med Microbiol. 2009; 27:107-10. | Article | PubMed

6. CLSI. Performance Standards for Antimicrobial Susceptibility Testing. 24th Informational Supplement. Clinical Laboratory Standards Institute. VET01-S2. 2013.

7. Guillemot D and Courvalin P. Better control of antibiotic resistance. Clin Infect Dis. 2001; 33:542-7. | Article | PubMed

8. Johnson JR, Kuskowski MA, Menard M, Gajewski A, Xercavins M and Garau J. Similarity between human and chicken Escherichia coli isolates 
Aminu et al. Microbiology Discovery 2015,

http://www.hoajonline.com/journals/pdf/2052-6180-3-6.pdf

in relation to ciprofloxacin resistance status. J Infect Dis. 2006; 194:71-8.

| Article | PubMed

9. Martinez MC, Retamal P, Rojas-Aedo JF, Fernandez J, Fernandez A and Lapierre L. Multidrug-Resistant Outbreak-Associated Salmonella Strains in Irrigation Water from the Metropolitan Region, Chile. Zoonoses Public Health. 2017; 64:299-304. | Article | PubMed

10. Obire O, Dumka G and Putheti R.R. Antimicrobial resistance in E. coli isolated from patients. Drug Intervention Today. 2009; 1:140-145.

11. Sawant AA, Hegde NV, Straley BA, Donaldson SC, Love BC, Knabel SJ and Jayarao BM. Antimicrobial-resistant enteric bacteria from dairy cattle. Appl Environ Microbiol. 2007; 73:156-63. | Article | PubMed Abstract | PubMed FullText

12. Schierack P, Steinruck H, Kleta S and Vahjen W. Virulence factor gene profile of Escherichia coli isolates from clinically healthy pigs. Applied Environmental Microbiology. 2006; 72:6680-6686.

13. Sorum $\mathrm{H}$ and Sunde $\mathrm{M}$. Resistance to antibiotics in the normal flora of animals. Vet Res. 2001; 32:227-41. | Article | PubMed

14. Tadesse DA, Zhao S, Tong E, Ayers S, Singh A, Bartholomew MJ and McDermott PF. Antimicrobial drug resistance in Escherichia coli from humans and food animals, United States, 1950-2002. Emerg Infect Dis. 2012; 18:741-9. | Article | PubMed Abstract | PubMed FullText

15. Wright GD. Antibiotic resistance in the environment: a link to the clinic? Curr Opin Microbiol. 2010; 13:589-94. | Article | PubMed

16. Rasheed MU, Thajuddin N, Ahamed P, Teklemariam Z and Jamil K. Antimicrobial drug resistance in strains of Escherichia coli isolated from food sources. Rev Inst Med Trop Sao Paulo. 2014; 56:341-6. | Article | PubMed Abstract | PubMed FullText

\author{
Citation: \\ Aminu RF and David I. Antimicrobial susceptibility \\ of commensal Escherichia coli from faeces of \\ apparently healthy white fulani cattle (Bos indicus). \\ Microbiol Discov. 2015; 3:6. \\ http://dx.doi.org/10.7243/2052-6180-3-6
}

